\title{
Performance of an aquaponics system using constructed semi-dry wetland with lettuce (Lactuca sativa L.) on treating wastewater of culture of Amazon River shrimp (Macrobrachium amazonicum)
}

\author{
Jô de Farias Lima ${ }^{1}$ (D) Sting Silva Duarte ${ }^{2} \cdot$ Argemiro Midonês Bastos $^{3} \cdot$ Taina Carvalho $^{2}$
}

Received: 20 September 2018 / Accepted: 5 February 2019

(C) Springer-Verlag GmbH Germany, part of Springer Nature 2019

\begin{abstract}
Aquaponics is a science that integrates animal aquatic production with vegetable culture in recirculating water systems. The performance of an aquaponics system using constructed semi-dry wetland with lettuce (Lactuca sativa L.) planted on treating wastewater of culture of shrimp Macrobrachium amazonicum was evaluated. Each aquaponics module consisted in four culture tanks $\left(1 \mathrm{~m}^{3} \operatorname{tank}^{-1}\right)$, conical sedimentation tank $\left(0.1 \mathrm{~m}^{3}\right)$, circular holding tank $\left(0.2 \mathrm{~m}^{3}\right)$, and constructed semi-dry wetland $(0.2 \mathrm{~m} \times 1.0 \mathrm{~m} \times 4.0 \mathrm{~m})$. Post larvae (PL) shrimps with an initial average mass of $314 \pm 4.75 \mathrm{mg}$ were stocked at density treatments in quadruplicate: (A) 40 shrimps $\mathrm{m}^{-2}$, (B) 80 shrimps $\mathrm{m}^{-2}$, and (C) 120 shrimps $\mathrm{m}^{-2}$. Our results showed the average final mass of shrimps had a slight reduction at the density 80 and 120 shrimps. However, it did not differ significantly between the treatments. The ultimate survival and productivity were higher in density 80 and 120 shrimps. The maximum biomass productivity occurred at the treatment with density 120 shrimps. The aquaponics recirculation system using constructed semi-dry wetlands with lettuce adequately treated the water at the densities tested. Various water quality parameters were deemed suitable for shrimp culture, but for lettuce not, especially the temperature. The shrimp density was inappropriate which limited the system to accumulate and increase the concentration of nutrients to vegetables with lessening the yield. Nonetheless, the system with higher density has higher nutrient content that plants demonstrated significantly better growth and yield. The results showed the potential use of organics waste generated in a family lettuce hydroponic production, but for a commercial production is indicated supplementation with nutrients like calcium, magnesium, and potassium in the water.
\end{abstract}

Keywords Recirculation aquaculture $\cdot$ Shrimp farming $\cdot$ Vegetables $\cdot$ Water treatment $\cdot$ Water reuse

\section{Introduction}

In September 2015, the UN Member States including Brazil adopted the 2030 Agenda for Sustainable Development,

Responsible editor: Philippe Garrigues

Jô de Farias Lima

jo.lima@embrapa.br

1 Agroforestry Research Center of Amapá-Embrapa Amapá, Rodovia Juscelino Kubitschek, Km 5, no. 2600, Mailbox 10, Macapa, Amapá 68906-970, Brazil

2 Fishing Engineering Course, State University of Amapá, Av. Presidente Vargas, no. 650, Mailbox 10, Macapa, Amapá 68900-000, Brazil

3 Federal Institute of Education, Science and Technology of Amapá, Rod. BR-210, Km 03, s/n, Brasil Novo, Macapa, Amapá 68909-398, Brazil which included sets aims for the contribution and conduct of fisheries and aquaculture towards food security and nutrition in the use of natural resources to ensure sustainable development in economic, social, and environmental terms (UNUnited Nations 2015).

Fisheries and aquaculture remain important sources of food, nutrition, income, and livelihoods for hundreds of millions of people around the world. World per capita fish supply reached estimates for 2014 and 2015 pointing towards further growth beyond $20 \mathrm{~kg}$, thanks to vigorous growth in aquaculture, which now provides half of all fish for human consumption, amounted to 73.8 million tons, with farmed crustaceans contributing 6.9 million tons (US\$36.2 billion) (FAO_Food and Agriculture Organization of the United Nations 2016). However, the conventional fish farming methods are rarely sustainable and they produce large amounts of nutrient-rich wastewater, partially loaded with chemicals used for fish treatment, which has a harmful effect on the receiving aquatic 
environment (Konnerup et al. 2011). Original approaches and technologies are needed in aquaculture aiming to achieve the sustainable development with higher productivity and lowest environmental impact as observed in 2030 Agenda (FAO 2016). In this context, aquaponics, which combines the integration of aquaculture recirculation systems (intensive cultivation of aquatic organisms) with hydroponics (land plants growing in aqueous solution), is emerging as an alternative for food production in level commercial or applied in small property scale to meet the requirements family farming as observed in many Brazilian city. In this system, the residual nutrients from aquaculture are mineralized by microorganisms and transformed into absorbable products by plants, supporting the development of plants and the maintenance of water quality (Castellani et al. 2009; Sace and Fitzsimmons 2013; Pinho et al. 2017). The "environmentally friendly" approach of this production system is due to the low use of water, minimal effluent discharge, nearly full utilization of aquafeeds, and the high productivity of aquatic organisms and plants compared with conventional productions (Dediu et al. 2012; Mariscal-Lagarda et al. 2012). Additionally, the possibility to produce in arid regions, nearby metropolitan centers and offer food pesticides and antibiotics-free, makes aquaponics a system that provides sustainable and high valueadded products (Diver 2006).

The aquaponic systems can be designed for small private installations or large commercial enterprises. Although contemporary aquaponics started with the first scientific papers being published around 1980, it really took off only after 2010 and today many aquaponic systems may be found all over the world. However, the social, financial, environmental, operational, and ecological basics are in many aspects unknown or fuzzy, and the technology still needs further research and development in order to progress (Junge et al. 2017).

The Brazilian academic literature is still poor and incipient in the aquaponics studies, and only in the last 10 years, researchers from some Brazilian Universities and from the Brazilian Agricultural Research Corporation (Embrapa) have undertaken research into this issue (Castellani et al. 2009; Hundley and Navarro 2013; Emerenciano et al. 2015; Carneiro et al. 2015; Geisenhoff et al. 2016). Among the aquaponics experiences using shrimps and vegetables, we cite the work of Castellani et al. (2009) and Pinheiro et al. (2017) who used the residual water of the Amazon river shrimp nursery (Macrobrachium amazonicum) and Litopenaeus vannamei, in the production watercress and lettuce, and Sarcophagus ambiguous, in nutrient film technique (NFT) hydroponic system, respectively. Generally, aquaponics is classified into three types, i.e., media-based bed, floating raft, and nutrient film technique. The NFT is less efficient at both removing nutrients from fish culture water and producing plant biomass or yield than gravel bed or floating hydroponic sub-systems (Lennard and Leonard 2006). Among them, media-based aquaponics is believed to be more efficient on nitrogen utilization since it could provide more surface area for microbes than the other two types, so it has been considered to be the most common and popular method for raising vegetal crops (Love et al. 2014).

An aquaponics system with high-yield, soil-less production requires high input of technology (pumps, aerators, loggers) and knowledge and is therefore mostly suited for commercial operations. However, it is entirely possible to design and operate low-tech aquaponics systems that require less skill to operate and still yield respectable results, especially in media-based aquaponics. This aquaponics system in fact is a constructed wetland that has a drenched and dry cycle (Love et al. 2014; Somerville et al. 2014; Trang and Brix 2014). Based on the principles commonly adopted in constructed wetlands, this technique enhances the purification capacity of the system. Actually, most of the designs of "hydroponic" component of "aquaponic" are similar to artificial treatment wetlands, serving as RAS for the purification of wastewater, which is connected to a tank for fish culture (Chen and Wong 2016). Integrated wetland techniques (such as hydroponic, constructed treatment wetland or floating island) with food production processes, coupled with polyculture of different fish species or other organisms including shrimps, are able to promote ecosystem health and achieve sustainability, mainly via its wastewater purification and nutrient recycling capability (Chen and Wong 2016). Thus, the question that arises is whether the variations in the biological filtration system using constructed wetland and different stocking density would influence the Amazon River shrimp and lettuce performance in an aquaponics.

The Amazon River shrimp M. amazonicum (Heller 1862) is an endemic species from South America, distributed in the rivers, floodplains, reservoirs, and lakes in tropical and subtropical regions of this continent (Maciel and Valenti 2009, Moraes-Valenti and Valenti 2010). This shrimp has great socioeconomic and environmental importance in the north and northeast regions of Brazil (Maciel and Valenti 2009) and good reception in the international markets (Damasceno et al. 2009). In the Amazon region, it is a most widely explored by artisanal fishing (Maciel and Valenti 2009). In aquaculture, this shrimp has demonstrated fast growth, rusticity, and satisfactory productivity, being indicated as an alternative that can avoids environmental impacts in Amazon region due to accidental escapes and the establishment of non-native shrimp in the natural environment as $M$. rosenbergii (Moraes-Valenti and Valenti 2010). It may adapt well for intensive or extensive farming and presents less aggressive behavior and ability to grow in reservoirs, ponds, and fishponds 
(Maciel and Valenti 2009). Our aim in this paper was to investigate the performance an aquaponics system using constructed wetland (media-based bed) with lettuce in treating wastewater of culture of Amazon River shrimp in different densities.

\section{Material and methods}

\section{Aquaponics units and recirculating system}

The experiment was conducted from August to October 2016 at the Laboratory of Aquiculture and Fishing of the Brazilian Agricultural Research Corporation, Embrapa, in the state of Amapá. The aquaponic experimental system consisted of tree identical aquaponic units, allowing replication of experimental treatments. Each aquaponic unit consisted of four culture tanks $\left(1 \mathrm{~m}^{3} \operatorname{tank}^{-1}\right)$, a conical sedimentation tank $\left(0.1 \mathrm{~m}^{3}\right)$, a circular holding tank $\left(0.2 \mathrm{~m}^{3}\right)$, and a constructed semi-dry wetland $(0.2 \mathrm{~m} \times 1.0 \mathrm{~m} \times 4.0 \mathrm{~m})$ used as a hydroponic sub-system and biofilter as shown in Fig. 1. The substrate of constructed semi-dry wetland was gravel with diameter of $2-3 \mathrm{~cm}$. A submersible pump with power of $4000 \mathrm{~L} \mathrm{~h}^{-1}$, which was actuated by a timer every $15 \mathrm{~min}$, controlled the flux of water among the sump and constructed wetland and shrimp tanks. The water retained in the constructed wetland was carried back to the sump by a bell siphon. The water culture tank flowed by gravity to the sedimentation unit for suspended solids removal. The wastewater collected in the circular holding tank is pumped to shrimp tanks and to the constructed semi-dry wetland, and from there, with the aid of a bell siphon, the treated water flowed by gravity to the holding tank. No water discharge or displacement occurred during the trial period, except when replacing the water lost through evaporation, siphoning the floor of the culture tanks, and cleaning the floor of the decanter tanks. The shrimp tanks floors were siphoned every day, and the decanter tanks bottom was cleaned every 2 days. To offset losses from nitrification, the $\mathrm{pH}$ buffering was accomplished by regularly adding hydrated lime. The system oxygenation was performed using a radial compressor with air stones ( 3 air stones $\mathrm{m}^{-2}$ ) connected to the shrimp tank and at the entrance of constructed semi-dry wetland.

\section{Shrimp culture and sampling}

Post larvae (PL) shrimps with an initial average mass of $314 \pm$ $4.75 \mathrm{mg}$ were stocked at density treatments in quadruplicate:

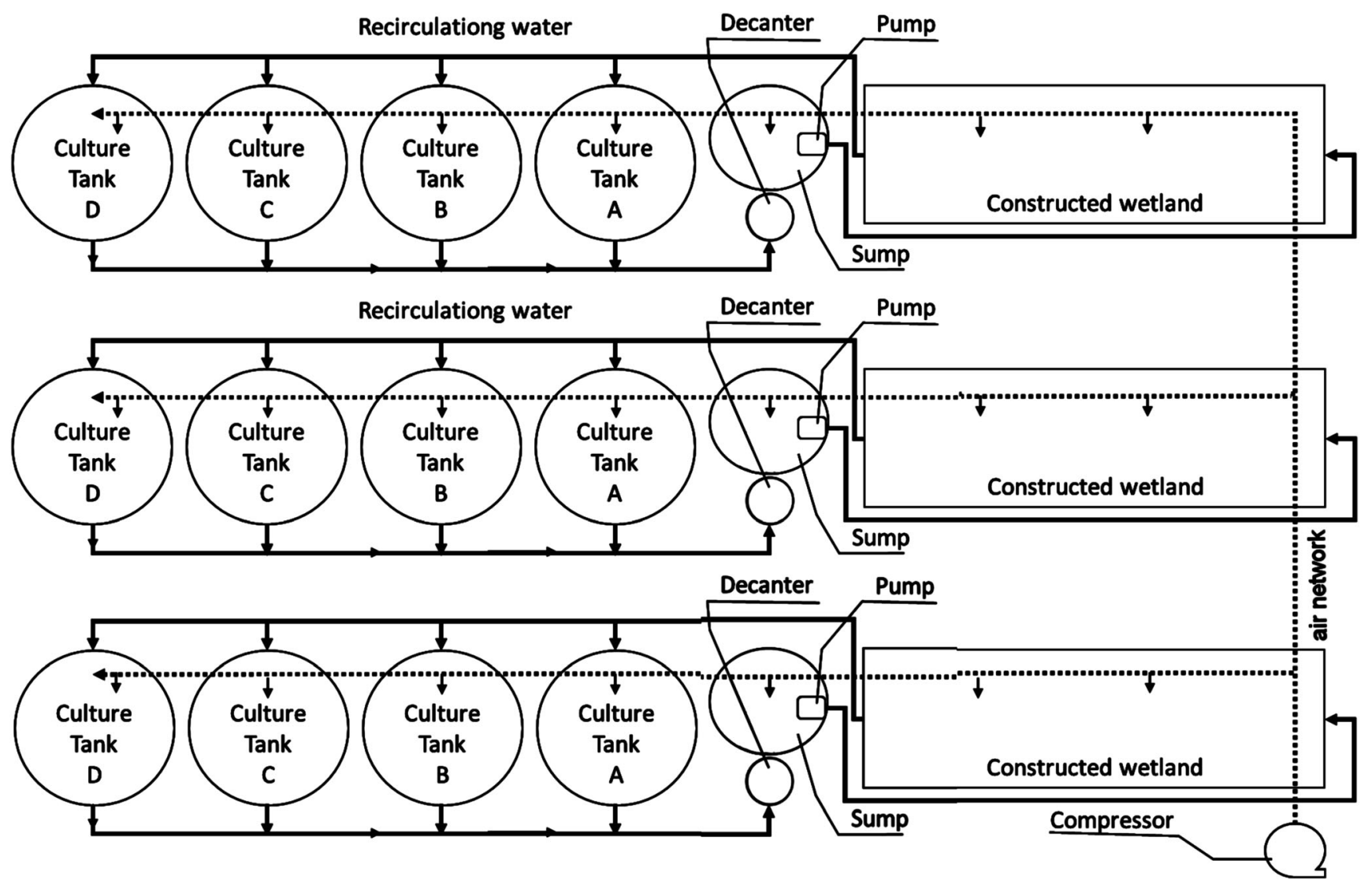

Fig. 1 A sketch depicting the components of the integrated shrimp-lettuce aquaponic system 
(A) 40 shrimps $\mathrm{m}^{-2}$, (B) 80 shrimps $\mathrm{m}^{-2}$, and (C) 120 shrimps $\mathrm{m}^{-2}$. The shrimps were fed with commercial pelleted food (GUABI ${ }^{\mathrm{TM}}$ ) being $36.0 \%$ protein, $5.5 \%$ lipid, $4.0 \%$ fiber, $10.6 \%$ ash, and $18.3 \mathrm{~kJ} \mathrm{~g}^{-1}$ gross energy. Shrimps were fed in the morning at 09:30 and late afternoon $16: 30 \mathrm{~h}$ daily at a rate of the $5 \%$ of the estimated biomass in the tank and adjusted on the weighted average weight of 20 shrimp samples taken every 15 days and partial survival (Lin et al. 2005). Pellets with $0.8 \mathrm{~mm}$ were used for the first 60 days, and pellets with $1.6 \mathrm{~mm}$ were used at to end the culture. Fortnightly, a sample of shrimp (about $5 \%$ of the number stocked) was collected and weighed in order to evaluate growth and to adjust the amount of feed supplied. After 110 days, food consumers $(\mathrm{kg})$ was determined by the sum of the feed provided to the shrimp and shrimps were individually counted and weighed to determine survival (\%), mean mass (g), total biomass $(\mathrm{kg})$, and productivity $\left(\mathrm{kg} \mathrm{ha}^{-1}\right)$. The feed conversion ratio (FCR) was calculated using the formula: FCR $=$ total feed dry weight / (final shrimp biomass - initial shrimp biomass) (Konnerup et al. 2011).

\section{Water sampling and analytical methods}

Water samples were obtained twice by weeks from the each holding tanks and shrimp tanks. Field measurements were done, and samples were collected at about 10:30 h, which was approximately $1 \mathrm{~h}$ after feeding. The samples were examined for total ammonia (TAN, $\left.\mathrm{mg} \mathrm{L}^{-1}\right)$, nitrite $\left(\mathrm{NO}_{2}^{-}, \mathrm{mg} \mathrm{L}^{-1}\right)$, nitrate nitrogen $\left(\mathrm{NO}_{3}^{-}, \mathrm{mg} \mathrm{L}^{-1}\right)$, total phosphorous $\left(\mathrm{H}_{2} \mathrm{PO}_{4}^{-}\right.$, $\mathrm{mg} \mathrm{L}^{-1}$ ) using multiparameter photometer for water analysis (HANNA ${ }^{\mathrm{TM}}$. Model HI83200). The physicochemical properties temperature $\left({ }^{\circ} \mathrm{C}\right), \mathrm{pH}$, dissolved oxygen $\left(\mathrm{DO}, \mathrm{mg} \mathrm{L}^{-1}\right)$, electrical conductivity $\left(\mathrm{EC}_{28}, \mathrm{mEq} \mathrm{L}^{-1}\right.$ ), turbidity (NTU), and total dissolved solids (TDS, ppm) were checked using multiparameter water quality checker (Horiba ${ }^{\mathrm{TM}}$ Model U-50) at approximately 10:30 every day during the culture period.

\section{Growth of hydroponic lettuce}

The cultivar used was Delice American lettuce (Isla). The seeds were germinated in a phenolic spume plate with 200 cells $(2.0 \times 2.0 \times 2.0 \mathrm{~cm})$. After germination, the seedlings were grown in a mini greenhouse, nourished with the nutrient solution from shrimp tank up to 15 days after sowing. At 15 days after sowing, the seedlings were transplanted to the constructed semi-dry wetland, $4 \mathrm{~m}$ long, spaced $0.25 \mathrm{~m}$ between profiles, and $0.25 \mathrm{~m}$ between plants as suggested by Genuncio et al. (2012). The growth of hydroponic plants was evaluated using leaf number, stalk, and root length. The yield $\left(\mathrm{g} \mathrm{m}^{-2}\right)$ was assessed using the fresh leaf mass $\left(\mathrm{g} \mathrm{plant}{ }^{-1}\right)$. The data from the first vegetables harvest were gathered 36 days after transplanting the plants (August 17September 22, 2015). The second crop was harvested 36 days after transplanting (October 05, 2015-November 09, 2015). Considering 10 days for preparing the system, culture period had lasted 110 days since Macrobrachium amazonicum was stocked in the shrimp tank.

\section{Statistical analyses}

The food consumers, survival (\%), mean mass (g), total biomass $(\mathrm{kg})$, productivity $\left(\mathrm{kg} \mathrm{ha}^{-1}\right)$, and feed conversion ratio were initially assuming a normal distribution and homoscedasticity using the Shapiro-Wilk and Bartlett tests, respectively. When these two requirements were met, ANOVA was applied followed by Tukey's test $(P<0.05)$, while they have not been fulfilled, mathematical transformations (ln) were performed. Water quality and growth of hydroponic lettuce data were submitted to the same statistical procedures previously reported. The statistical analysis of the data was performed with the aid of the BioEstat 5.0® software (AYRES et al. 2007).

\section{Results}

\section{Performance shrimp}

The consumed food differed significantly between the treatments $(P<0.05)$. The mean of total shrimp diets were $6.50 \mathrm{~kg}$, $15.90 \mathrm{~kg}$, and $28.62 \mathrm{~kg}$, respectively in $\mathrm{T} 1, \mathrm{~T} 2$, and T3. Total commercial shrimp harvest differed significantly between the treatments $(P<0.05)$, being $2.8 \mathrm{~kg}, 10.4 \mathrm{~kg}$, and $14.5 \mathrm{~kg}$. FCR differed significantly between the treatments $(P<0.05)$, being $2.37 \pm 0.49,1.55 \pm 0.4$, and $2.04 \pm 0.05$, respectively. The average weight did not differ significantly $(P<0.05)$ among the treatments, with $\mathrm{T} 1=1.77 \pm 0.46 \mathrm{~g}, \mathrm{~T} 2=1.72 \pm 0.22 \mathrm{~g}$, and $\mathrm{T} 3=1.65 \pm 0.60 \mathrm{~g}$, respectively (Table 1 ).

At the end of the experimental period, shrimp cultured at 40 stocking density not exhibited an excellent mean survival rate than those at 80 and 120 shrimps. In this trial, the final survival was significantly differ $(P<0.05)$ among treatments, with average survival in the culture tanks: $\mathrm{T} 1=40.0 \pm 7.36 \%, \mathrm{~T} 2=$ $76.3 \pm 19.93 \%$, and $\mathrm{T} 3=71.04 \pm 5.57 \%$, respectively. The final productivity by area was significantly differ $(P<0.05)$ among treatments with $\mathrm{T} 1=283.5 \pm 47.26 \mathrm{~kg} \mathrm{ha}^{-1}, \mathrm{~T} 2=$ $1049.6 \pm 134.58 \mathrm{~kg} \mathrm{ha}^{-1}$, and T3 $=1405.4 \pm 85.34 \mathrm{~kg} \mathrm{ha}^{-1}$, respectively. The highest shrimp productivity in biomass was observed at the treatment with density 120 shrimps, due to the highest survival, although individual final mass has been slightly low (Table 1).

\section{Water quality of the aquaponics system}

Table 2 shows average values and standard deviation to water quality parameters evaluated in the present study. Temperature, nitrite, hardness, potassium, calcium, and 
Table 1 Growth response (mean \pm standard deviation) of shrimps reared for 90 days at different storage densities in a recirculation system using constructed semi-dry wetlands with lettuce

\begin{tabular}{|c|c|c|c|c|c|}
\hline & \multicolumn{3}{|l|}{ Treatments } & \multirow[t]{2}{*}{$F$} & \multirow[t]{2}{*}{$P$} \\
\hline & 40 shrimps & 80 shrimps & 120 shrimps & & \\
\hline Food consumers (kg) & $6.5 \pm 3.20 \mathrm{a}$ & $15.9 \pm 3.40 \mathrm{~b}$ & $28.2 \pm 2.70 \mathrm{c}$ & 162.84 & 0.001 \\
\hline FCR & $2.37 \pm 0.49 a$ & $1.55 \pm 0.40 \mathrm{~b}$ & $2.04 \pm 0.50 \mathrm{a}$ & 4.996 & 0.035 \\
\hline Total biomass (kg) & $2.8 \pm 2.10 \mathrm{a}$ & $10.4 \pm 1.50 \mathrm{~b}$ & $14.5 \pm 1.30 \mathrm{c}$ & 142.74 & 0.001 \\
\hline Mean mass (g) & $1.77 \pm 0.46 \mathrm{a}$ & $1.72 \pm 0.22 \mathrm{ab}$ & $1.65 \pm 0.60 \mathrm{~b}$ & 7.785 & 0.011 \\
\hline Survival & $40.00 \pm 7.36 \mathrm{a}$ & $76.30 \pm 19.93 b$ & $71.04 \pm 5.57 b$ & 23.970 & 0.001 \\
\hline Productivity $\left(\mathrm{kg} \mathrm{ha}^{-1}\right)$ & $283.50 \pm 47.26 \mathrm{a}$ & $1049.6 \pm 134.58 b$ & $1405.40 \pm 85.34 \mathrm{c}$ & 142.74 & 0.001 \\
\hline
\end{tabular}

Values reported are mean \pm SD for four replicates and the same growth parameter of M. amazonicum. Different letters in superscript show significant differences

magnesium values varied within a narrow range and did not differ statistically among the treatments. PH differ statistically among the treatments, it had little oscillation being slightly alkaline in T1 and T2 and almost neutral in T3. Electrical conductivity was stable in all treatments, being statistically higher in T3. Dissolved oxygen did not differ statistically among treatments but was reduced with density increase possibly due to higher oxygen (Table 2). Turbidity and total ammonia varied within a narrow range and did differ statistically among the treatments, being higher in treatments T2 and T3.

Total dissolved solids, nitrate, phosphate, and alkalinity average values were statistically higher in treatments T3 (Table 2). Details on dynamics of temperature, $\mathrm{pH}$, conductivity, dissolved oxygen, and turbidity parameters are presented in Fig. 2a-e. Temperature and dissolved oxygen varied within a narrow range throughout the experiment (Fig. 2a, d), while $\mathrm{pH}$ values from the 60th day, this presented slight reduction in 120 shrimps treatment (Fig. 2b). The conductivity and turbidity values significantly increased on the 10th day of cultivation in all treatment (Fig. 2c-e).

The TDS values increased on the 10th day of cultivation in all treatment, but in the 60th day, TDS values in 120 shrimps treatment have shown strong increase (Fig. 3a). The TAN produced by the shrimp tank in the beginning of the experiment was high, but it suffered heavy drop after maturation of the biological filtration system on the 10th day of cultivation in all treatment (Fig. 3b). On the other hand, the nitrite and nitrate values in the beginning of the experiment were low and

Table 2 Water quality parameters from shrimp tank water in different stocking densities in aquaponics system using semi-dry constructed wetlands

\begin{tabular}{|c|c|c|c|c|c|c|}
\hline \multirow[t]{2}{*}{ Parameters } & \multirow[t]{2}{*}{ Unit } & \multicolumn{3}{|l|}{ Stocking densities } & \multirow[t]{2}{*}{$F$} & \multirow[t]{2}{*}{$P$} \\
\hline & & 40 shrimps & 80 shrimps & 120 shrimps & & \\
\hline Temperature & ${ }^{\circ} \mathrm{C}$ & $28,65 \pm 1,37 \mathrm{a}$ & $28.66 \pm 1.37 \mathrm{a}$ & $28.75 \pm 1.28 \mathrm{a}$ & 0.165 & 0.848 \\
\hline $\mathrm{pH}$ & & $7.59 \pm 0.79 a$ & $7.59 \pm 0.59 \mathrm{a}$ & $7.03 \pm 0.82 b$ & 17.496 & $<0.001$ \\
\hline Conductivity & $\mu \mathrm{S} \mathrm{cm} \mathrm{cm}^{-1}$ & $157.72 \pm 24.81 \mathrm{a}$ & $158.09 \pm 26.28 \mathrm{a}$ & $183.28 \pm 36.07 \mathrm{~b}$ & 24.427 & $<0.001$ \\
\hline Turbidity & NTU & $1.65 \pm 0.67 \mathrm{a}$ & $3.21 \pm 1.14 \mathrm{~b}$ & $4.13 \pm 1.30 \mathrm{c}$ & 123.008 & $<0.001$ \\
\hline DO & $\mathrm{mg} \mathrm{L}^{-1}$ & $7.43 \pm 106 \mathrm{a}$ & $7.27 \pm 0.94 \mathrm{a}$ & $7.21 \pm 0.90 \mathrm{a}$ & 1.394 & 0.250 \\
\hline TDS & ppm & $101.43 \pm 16.18 \mathrm{a}$ & $102.79 \pm 16.74 a$ & $119.97 \pm 23.77 b$ & 26.330 & $<0.001$ \\
\hline TAN & $\mathrm{mg} \mathrm{L}^{-1}$ & $0.33 \pm 0.26 \mathrm{a}$ & $0.51 \pm 0.28 b$ & $0.73 \pm 0.52 \mathrm{c}$ & 6.760 & 0.002 \\
\hline $\mathrm{NO}_{2}-\mathrm{N}$ & $\mathrm{mg} \mathrm{L}^{-1}$ & $0.047 \pm 0.05 \mathrm{a}$ & $0.052 \pm 0.02 \mathrm{a}$ & $0.067 \pm 0.03 \mathrm{a}$ & 1.881 & 0.160 \\
\hline $\mathrm{NO}_{3}-\mathrm{N}$ & $\mathrm{mg} \mathrm{L}^{-1}$ & $14.2 \pm 10.71 \mathrm{a}$ & $18.04 \pm 10.26 \mathrm{a}$ & $27.4 \pm 12.67 b$ & 8.412 & 0.001 \\
\hline $\mathrm{H}_{2} \mathrm{PO}_{4-}$ & $\mathrm{mg} \mathrm{L}^{-1}$ & $1.98 \pm 2.20 \mathrm{a}$ & $3.94 \pm 4.22 \mathrm{a}$ & $9.84 \pm 7.17 b$ & 13.902 & 0.001 \\
\hline $\mathrm{K}_{2} \mathrm{O}$ & $\mathrm{mg} \mathrm{L}^{-1}$ & $2.71 \pm 1.19 \mathrm{a}$ & $3.11 \pm 2.28 \mathrm{a}$ & $3.26 \pm 2.31 \mathrm{a}$ & 1.865 & 0.162 \\
\hline Alkalinity & $\mathrm{CaCO}_{3} \mathrm{mg} \mathrm{L}^{-1}$ & $19.00 \pm 73 a$ & $20.80 \pm 8.86 \mathrm{a}$ & $25.72 \pm 11.51 \mathrm{~b}$ & 3.333 & 0.041 \\
\hline Hardness & $\mathrm{CaCO}_{3} \mathrm{mg} \mathrm{L}^{-1}$ & $1.05 \pm 0.38 \mathrm{a}$ & $1.32 \pm 0.51 \mathrm{a}$ & $1.29 \pm 0.35 \mathrm{a}$ & 1.753 & 0.181 \\
\hline $\mathrm{Mg}^{2+}$ & $\mathrm{mg} \mathrm{L}^{-1}$ & $0.21 \pm 0.07 \mathrm{a}$ & $0.24 \pm 0.06 \mathrm{a}$ & $0.19 \pm 0.08 \mathrm{a}$ & 2.054 & 0.136 \\
\hline $\mathrm{Ca}^{2+}$ & $\mathrm{mg} \mathrm{L}^{-1}$ & $0.80 \pm 0.08 \mathrm{a}$ & $0.11 \pm 0.11 \mathrm{a}$ & $0.12 \pm 0.09 \mathrm{a}$ & 0.891 & 0.415 \\
\hline
\end{tabular}

Values reported are mean \pm SD for four replicates and the same growth parameter average value with various letters in superscript show significant differences 

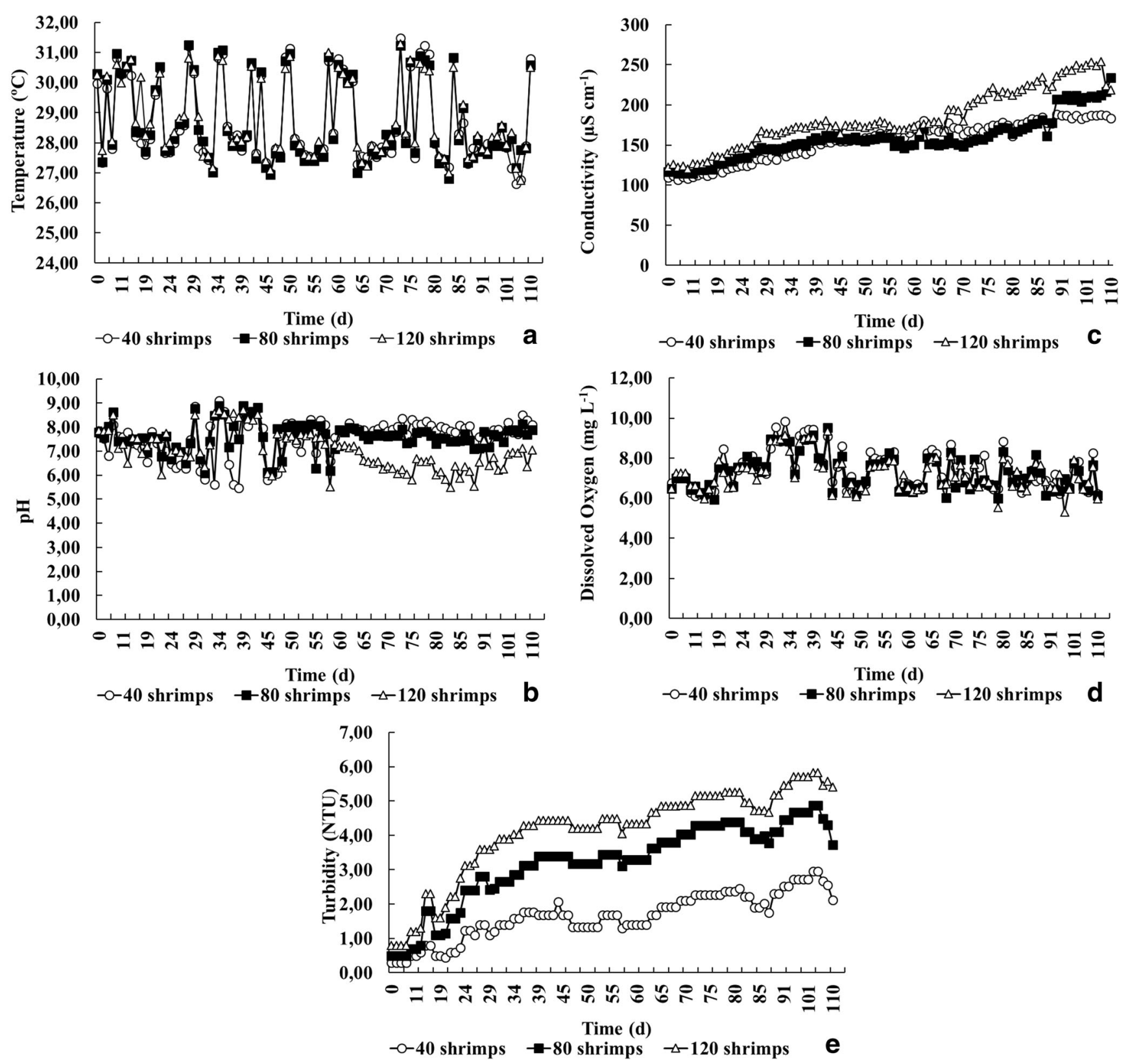

Fig. 2 Dynamics of water quality parameters from shrimp tank in different stocking densities in aquaponics system using semi-dry constructed wetlands. a Temperature. b pH. c Conductivity. d Dissolved oxygen. e Turbidity

after maturation of the biological filtration system on the 10th day of cultivation, these parameters increased in all treatment (Fig. 3b-d). Alkalinity varied within a narrow range throughout the experiment in all treatment (Fig. 3e).

The parameters potassium, hardness, calcium, and magnesium did not differ statistically between the treatments (Table 2). Same with increased as in the amount of feed supplied to shrimps, the potassium values decreased over the course of culture after an introduction of lettuces on the 10th day of cultivation (Fig. 4a), indicating that potassium present in the fed supplied to shrimps was not satisfactory to maintain ideal values of this parameter to the lettuces. On the other hand, the phosphate values at the beginning of the experiment were low, and after maturation of system on the 32nd day of cultivation, this parameter increased in all treatment, especially in 120 shrimps' treatment (Fig. 4c). Hardness and calcium fluctuated strongly throughout the trial but remained close to the beginning of the experiment (Fig. $4 \mathrm{~b}-\mathrm{d}$ ), while magnesium values presented a slight decrease especially in 40 shrimps treatment (Fig. 4e). The parameters alkalinity, hardness, calcium, and magnesium oscillated during the cultivation in all treatments (Fig. $4 \mathrm{~b}-\mathrm{e}$ ). 

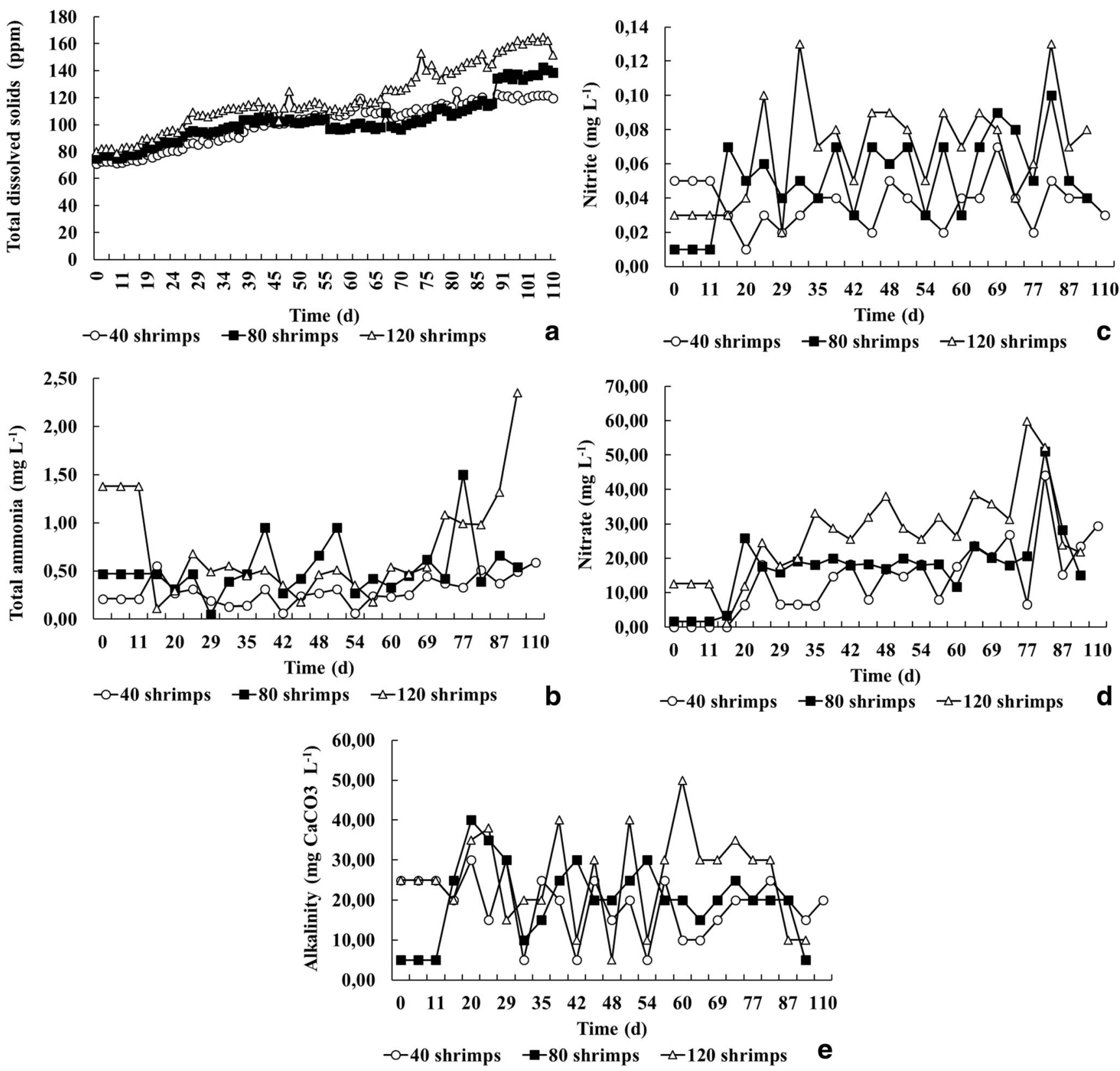

Fig. 3 Dynamics of water quality parameters from shrimp tank in different stocking densities in aquaponics system using semi-dry constructed wetlands. a TDS. b Total ammonia. c Nitrite. d Nitrate. e Alkalinity

\section{Growth of hydroponic crops}

The results showed the potential for the nutrient shrimp water use on lettuce production. The statistical ANOVA analysis revealed that there was a significant difference on the number of leaves, stalk length, leaf mass, and yield lettuce $\left(\mathrm{g} \mathrm{m}^{-2}\right)$ between densities studied. Lettuces farmed with pond water of 120 shrimps had significantly higher leaves number $(P<0.05)$ than those supplied with pond water of 40 shrimps and 80 shrimps treatments (Table 2). The maximum leaf mass, length stalk, and lettuce yield $\left(\mathrm{g} \mathrm{m}^{-2}\right)(P<0.05)$ were observed in the 120 shrimps treatment (Table 3). Only the root length had no significant effects.

\section{Discussion}

\section{Performance shrimp}

The stocking density of shrimp is one of the vital zootechnical factors that directly influence on feeding, survival, growth, behavior, health, yield, and profit (Marques et al. 

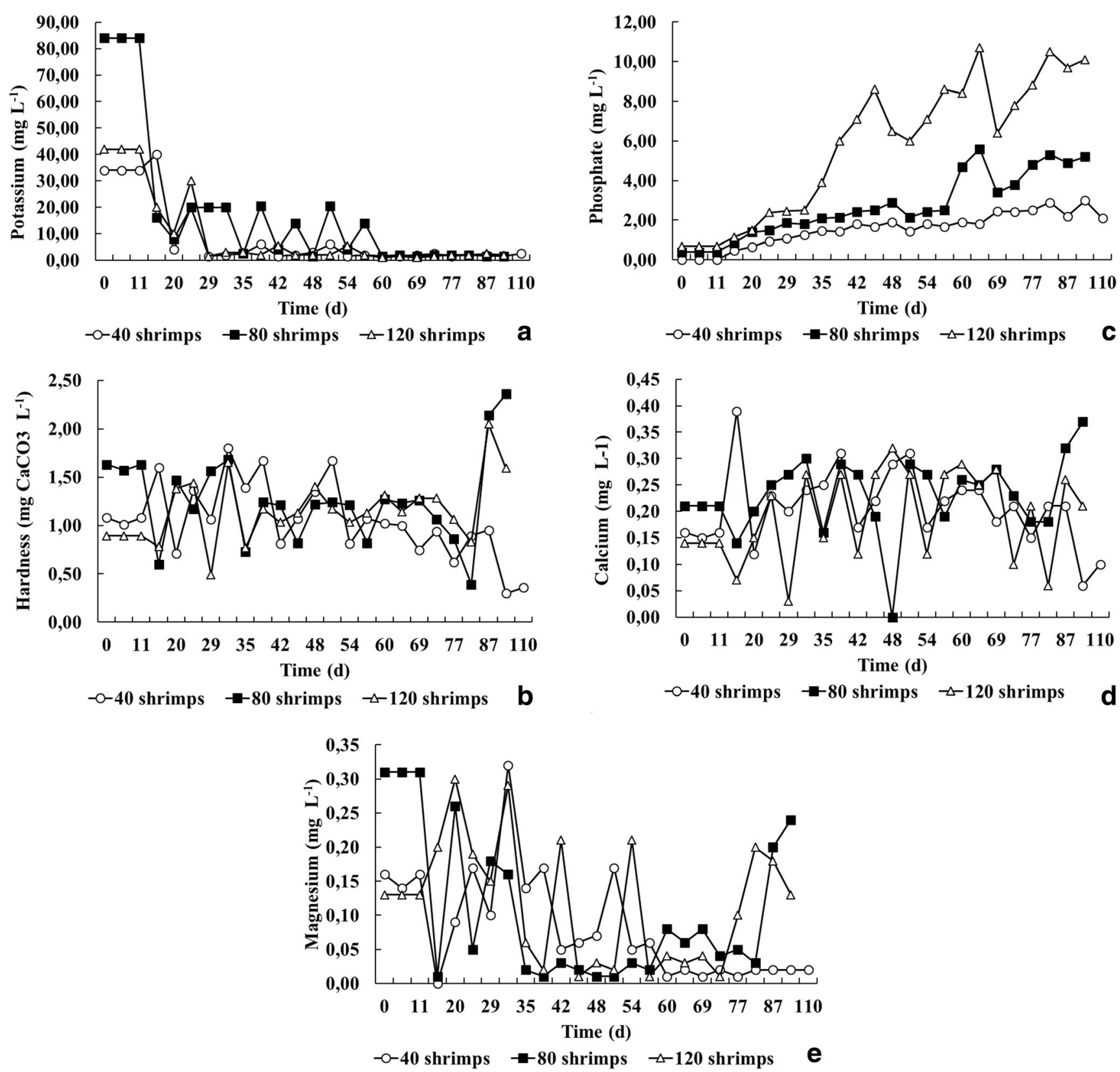

Fig. 4 Dynamics of water quality parameters from shrimp tank in different stocking densities in aquaponics system using semi-dry constructed wetlands. a Potassium. b Hardness. c Phosphate. d Calcium. e Magnesium

2012; Henry-Silva et al. 2015). An inverse relationship between stocking density and growth has been reported for M. amazonicum in different farming systems, suggesting that higher stocking densities could negatively influence final yield this shrimp (Moraes-Valenti and Valenti 2007; MoraesValenti et al. 2010; Marques et al. 2012; Henry-Silva et al. 2015). This fact was observed in the present study; our results showed that $M$. amazonicum individual mass had a slight reduction at the 120 shrimps treatment differing significantly $(P<0.05)$ of 40 shrimps treatment. In crowded conditions, conflicting results were observed in others species suggesting that in shrimps, the intraspecific competition has important paper and can influence the regulation of population, but it does not affect the weight and growth performance (El-Sherif and Mervat 2009; Paul et al. 2016; Negrini et al. 2017).

Shrimp survival in this trial was similar to reported by Preto et al. (2010, 2011), Marques et al. (2012), and Dutra et al. (2016), suggesting that the culture conditions were suitable for M. amazonicum development. The hypothesis of a greater survival in dealing with low density was not observed in this study, corroborating that M. amazonicum tolerates intensification and can be raised in both semi-intensive and intensive systems with high survival and productivity using densities beyond $40 \mathrm{~m}^{-2}$ (Moraes-Valenti and Valenti, 2007, Marques 
Table 3 Growth response of lettuce plants using nutrient rich shrimp tank water in different stocking densities

\begin{tabular}{|c|c|c|c|c|c|}
\hline & \multicolumn{3}{|l|}{ Stocking densities } & \multirow[t]{2}{*}{$F$} & \multirow[t]{2}{*}{$P$} \\
\hline & 40 shrimps & 80 shrimps & 120 shrimps & & \\
\hline Number of leaves & $14.10 \pm 2.51 \mathrm{a}$ & $16.00 \pm 2.0 \mathrm{a}$ & $18.6 \pm 1.5 b$ & 12.162 & $<0.001$ \\
\hline Length of stalk ( $\mathrm{cm} \mathrm{plant}^{-1}$ ) & $7.1 \pm 2.3 \mathrm{a}$ & $7.3 \pm 1.2 \mathrm{a}$ & $11.8 \pm 2.1 \mathrm{~b}$ & 19.089 & $<0.001$ \\
\hline Length of roots $\left(\mathrm{cm} \mathrm{plant}^{-1}\right)$ & $9.7 \pm 2.7 \mathrm{a}$ & $10.2 \pm 1.5 \mathrm{a}$ & $9.2 \pm 1.9 \mathrm{a}$ & 2.373 & 0.112 \\
\hline Leaf mass $\left(\mathrm{g} \mathrm{plant}^{-1}\right)$ & $50.97 \pm 17.16 \mathrm{a}$ & $61.57 \pm 10.40 \mathrm{a}$ & $76.15 \pm 18.8 b$ & 8.527 & $<0.001$ \\
\hline Yield $\left(\mathrm{g} \mathrm{m}^{-2}\right)$ & $957.65 \pm 500.71 \mathrm{a}$ & $1108.73 \pm 298.8 \mathrm{a}$ & $1924.57 \pm 477.7 b$ & 6.028 & 0.007 \\
\hline
\end{tabular}

Values reported are mean \pm SD for three replicates and the same growth parameter average value with different letters in superscript show significant differences $(P<0.05)$

et al. 2012). This shrimp shows a dynamic and densitydependent population structure. Apparently, high density may change the morphotype population structure, affecting intraspecific competition for space and food (Moraes-Valenti et al. 2010). Our data suggests that high density promoted a breach of hierarchy and a gregarious behavior, with less aggressive in $M$. amazonicum. However, the competition for food may limit the shrimp growth.

Although, the productivity in the present work was lower than that reported by Moraes-Valenti and Valenti (2007). Our results also showed that higher densities are more productive and that the additional biomass comprised small shrimps. As suggested by Moraes-Valenti and Valenti (2007), an economic analysis must be conducted to confirm if higher densities are advantageous from the economic point of view use of intensive systems. It should also be noted that the shrimp productivity might be improved by increasing stocking density and using substrates and aeration in static ponds (Karplus and Sagi 2010). The substrates are natural screens (e.g., bamboo, branches) or artificial screens (e.g., screens, nets) installed inside the culture ponds to increase the production area; especially, benthic organisms reduce heterogeneous growth and agonistic behavior like well and improve animal welfare (Karplus and Sagi 2010). The addition of substrates allows the growth of periphyton, which absorbs nitrogen and phosphorus, enhancing water quality, and provides food to the shrimps (Tidwell \& Bratvold 2005; Henares et al. 2015). In this study, no substrate was used in the shrimp culture tanks that have limited space. Probably, the limited space may have triggered competition for food that has interfered with shrimp growth. This fact may affect the food competition. Therefore, the addition of substrates probably will allow that shrimp productivity might improve in the Aquaponic system.

\section{Water quality and growth of hydroponic crops}

Several biotic and abiotic processes regulate pollutant removal in an aquaponics system using constructed wetlands (Shi et al. 2011). Among the biological processes, we have microbial mineralization and transformation (e.g., nitrification-denitrification) and uptake by vegetable, whereas chemical precipitation, sedimentation, and substrate adsorption are included in abiotic processes (Lin et al. 2005). In this trial, the aquaponics recirculation system using constructed semi-dry wetlands planted with lettuces was satisfactorily efficient like water treatment filters at the densities tested, reducing key pollutants from shrimp culture water, as we shall see below. Even so, the high survival rate and productivity obtained in this experiment suggest that water variables were acceptable for M. amazonicum development. However, nutrient mineralized and transformed was not sufficient for adequate lettuce production.

In this trial, temperature of the water was warm enough to stimulate good shrimp growth rates and at the same time enough to carry maximum oxygen content for all species in the system including the bacteria, as observed in others aquaponics (Rakocy et al. 2006; Sace and Fitzsimmons, 2013 and Zou et al. 2016). The temperature and $\mathrm{pH}$ remained within the range recommended for $M$. amazonicum cultivation (Moraes-Riodades et al. 2006; Moraes-Valenti and Valenti 2007, 2010), and similar to observed in his natural habit, which shows temperature between 27.5 and $31^{\circ} \mathrm{C}$, dissolved oxygen between 4.6 and $6.1 \mathrm{mg} \mathrm{L}^{-1}$, and $\mathrm{pH}$ value between 7.4 and 8.4 (Sampaio et al. 2007). However, the lettuces have optimal growth with temperatures near $24{ }^{\circ} \mathrm{C}$ (Rakocy et al. 2006), suggesting that the temperature observed in this trial did not remain within of recommended for lettuce cultivation, as the increase in the flow rate is a factor that might favor lower temperatures and higher DO concentrations in nutritive solution, due to less exposure of the nutritive solution during the time of increased incidence of solar radiation (Genuncio et al. 2012). We suggest that water flow rate between shrimp tank and wetland being increased, reducing at the timer control the interval of every water pump activation. Another suggestion is the choice of lettuce cultivars adapted to higher temperatures as observed by Rodrigues et al. (2008) studying the performance of lettuce cultivars in the region of Manaus, in the North of Brazil. Moreover, temperature, DO, $\mathrm{pH}$, 
nitrogen compounds, and alkalinity mean values recorded in this study corroborated with usual values observed in aquaponics systems (Sikawa and Yakupitiyage 2010; Roosta 2014; Zou et al. 2016).

Significant oxygen demand exists in the wetlands both associated with the incoming wastewater or like latent demand by entrapped wastes or ongoing waste conversion processes (Zachritz II et al. 2008). Hence, oxygen is strongly indicated as the limiting factor for M. amazonicum; the limnologic variables remained within the appropriate range for the biology of species farmed in other aquaculture systems (Preto et al. 2008; Marques et al. 2012; Dutra et al. 2016). Besides respiration, the organic waste decomposition in the pond bottom consumed oxygen in the water. Consequently, it is highly important to take into account the quantity and quality of feed given to shrimps. Aerators' presence in this study improved the performance of the overall wetland in treating wastewater from recirculating and proved ideal oxygenation suggested for shrimps by Sampaio et al. (2007). In the constructed semidry wetland, the installation of air stones improves oxygenation and provides organic stabilization and nitrification (Zhang et al. 2011). Similarly, an adequate oxygenation with $5 \mathrm{mg}^{-1}$ or higher for maximum health and animal growth, plants, and nitrifying bacteria is essential in an aquaponics system (Rakocy 2007). It suggests that the DO concentrations observed in this trial proved good oxygenation for an aquaponics system.

Controlling $\mathrm{pH}$ value in aquaponics systems is crucial to synergic between microbial and plant demands (Zou et al. 2016). Microbial ammonia nitrification to nitrite and nitrite to nitrate are optimized at $\mathrm{pH} 8.5$, but plant nutrient uptake for many crop species is optimized near $\mathrm{pH} 6.0$; thus, $\mathrm{pH}$ in aquaponics systems must be managed near neutral value (7.0), which should is optimal for plant growth and nitrification efficiency (Zou et al., 2016). In this trial, pH data suggests that it was within the appropriate range for the M. amazonicum biology, but not for common lettuce requirements, except in treatment with 120 shrimps, which $\mathrm{pH}$ value was adequated for microbial nitrification and plant demands.

The chemical composition of aquaponics nutrient solutions is complex, because of a large number of dissolved ions and organic substances resulting from the release of excretory compounds as a product of aquatic organisms metabolism and feed digestion. In this trial, the $\mathrm{pH}$ value can influence the interaction between the dissolved ions as observed in electrical conductivity and total dissolved solids. In relation to the nitrogen compounds (ammonia, nitrite, and nitrate) and alkalinity, the $\mathrm{pH}$ effects was not evident. But in phosphate, it possibly caused the increase of this parameter especially in the treatment with 120 shrimps, where the $\mathrm{pH}$ value was lower as observed by Cerozi and Fitzsimmons (2016) that recommended $\mathrm{pH}$ in aquaponics systems at a 5.5-7.2 range for optimal availability and uptake by plants. However, phospate and nitrogen compound (ammonia, nitrite, and nitrate) concentrations are related to the addition of feed in the Macrobrachium amazonicum culture tanks, which generate many organic wastes (non-consumed feed, feces, and others) in the sediment (Nogueira et al. 2014).

The readings of TDS were within the appropriate range for the M. amazonicum biology, but not for average requirements of the lettuce. This vegetable has grown well with TDS of $560-840 \mathrm{ppm}$ in an aquaponics system (Zachritz II et al. 2008; Sace and Fitzsimmons 2013).

Timmons et al. (2002) recommended total ammonia concentration below $3 \mathrm{mg} \mathrm{L}^{-1}$ and nitrite below $1 \mathrm{mg} \mathrm{L}^{-1}$ in recirculation system aquaculture. In this study, we observed increases in density contributed to increases in nitrogen compounds especialy nitrate $\left(\mathrm{NO}_{3} \mathrm{~N}\right)$. However, the total ammonia data and nitrite observed in this trial below the suggested values for the M. amazonicum cultivation (Moraes-Valenti and Valenti 2007, 2010; Nogueira et al. 2014, Zou et al. 2016). Between nitrogen compounds, $\mathrm{NO}_{3}-\mathrm{N}$ is the end product of nitrification and also the main nutrient for plant growth in aquaponics, and thus concentration observed in the water is the equilibrium result between nitrification and plant absorption (Zou et al. 2016). In this trial, $\mathrm{NO}_{3}-\mathrm{N}$ contration was satisfactory to lettuce production only at threatment with 120 shrimps.

Alkalinity is an important water quality criterion for fish and shrimp culture. When the water has low alkalinity $(<$ $20 \mathrm{mg} \mathrm{L}^{-1} \mathrm{CaCO}_{3}$ ), it is less suitable for fish and shrimp culture due to the associated unstable water chemistry (Adhikari et al. 2007). Therefore, for successful shrimp culture development, hardness and alkalinity should be properly monitored, and maintained for a sustainable production (Adhikari et al. 2007). These authors have suggested that Macrobrachium rosenbergii has a better grown in hard water between 92 and $192 \mathrm{mg} \mathrm{L}^{-1}$ concentration of calcium hardness and $100 \mathrm{mg} \mathrm{L}^{-1} \mathrm{CaCO}_{3}$ of bicarbonate alkalinity (Adhikari et al. 2007). As a result, the alkalinity observed in this trial cannot be suitable for $M$. amazonicum culture.

Hardness is a measure of water's calcium and magnesium. In general, freshwater shrimps in hard water (50 to $200 \mathrm{mg} \mathrm{L}^{-1}$ $\mathrm{CaCO}_{3}$ ) tend to spend less energy on osmoregulation, resulting in an optimum growth of shrimps (Wetzel 2001). Calcium is critical to freshwater shrimps in keeping exoskeletons secure, and when hardness is too low, this animal will take longer time after a molt for the exoskeleton to harden, allowing the animal to become vulnerable to the predators' attack and aggressions (Adhikari et al. 2007). Shrimps exposed to soft water are more susceptible to other water quality conditions also, and very hard water can be a problem (Adhikari et al. 2007). In this trial, the hardness was extremely low in all treatments, and probably, it could have influenced the survival and growth of the shrimps, not being suitable for M. amazonicum culture. Moreover, calcium and magnesium 
are essential nutrients for lettuce and in hydroponics system; it is one of the first to decline (Seawright et al. 1998). In aquaponic systems, the calcium is an essential nutrient because both animal (shrimps and fishes) and plants use this element in various metabolic activities, and calcium in very low or very high concentrations can negatively affect the metabolism of these organisms (Seawright et al. 1998). Data reported by Seawright et al. (1998) suggests that an aquaponic system could need additional calcium in the system up to $200 \mathrm{mg} \mathrm{L}^{-1}$; otherwise, plants may present inadequate responses. Our results indicate that the calcium and magnesium values observed were not ideal for lettuce growth even after addition of hydrated lime.

As reported by Sikawa and Yakupitiyage (2010) and Sace and Fitzsimmons (2013), the major constraints to use of aquaculture farming water for lettuce production are found to be a low macronutrients concentration, low dissolved oxygen, and high suspended solids. The organic waste volume generated in this trial probably did not provide adequate nutrition for lettuce. It is noteworthy that the lettuce growth has an interrelationship with ionic concentration and the flow rate of the nutrient solution, which are relevant variables at the nutrient availability and water retention in a hydroponic system (Genuncio et al. 2012; Guimarães et al. 2016).

The observed lettuce yield (leaves number and leaf mass) was relatively superior than the values reported by Sikawa and Yakupitiyage (2010), but lower than the values reported by Seawright et al. (1998) and Rakocy et al. (2006) in an aquaponics system, in which effluent was enriched with a nutrient solution. Although no additional nutrient solution has been included in this trial, except hydrated lime, the lettuce biomass obtained was similar to the values reported by Castellani et al. (2009) who also investigated the integration of the freshwater shrimp culture with a hydroponic system and by Guimarães et al. (2016) who grew lettuce plants hydroponically using saline wastewater from fish farming. Our lettuce yield was relatively lower than the values reported by Genuncio et al. (2012) who grew lettuce plants hydroponically using nutrient solutions. It indicates the potential for the use of nutrient M. amazonicum tank water for supplying a family hydroponic production of lettuce. However, for a commercial lettuce production, additional nutrients are necessary.

\section{Conclusion}

In the study presented, we investigated the performance of an aquaponics system using constructed semi-dry wetland with lettuce planted on treating wastewater from shrimp Macrobrachium amazonicum culture. Our results suggests that the aquaponics recirculation system, using constructed semi-dry wetlands with lettuces, was satisfactorily efficient like water treatment filters at the densities tested, removing the main pollutants from shrimp culture water. M. amazonicum showed a strong tolerance to the highest densities. Although, the animal growth did not differ significantly between the treatments for mass, which was contrary to the hypothesis of a greater gain in mass in low density. The density of 120 shrimps had satisfactory shrimp productivity, but it was unsuitable to lettuce nutrition that has shown inferior yield to traditional hydroponics. A strong association between the nutrient concentration in the culture water and lettuce production was observed. The shrimp farming effluent may be managed in a family lettuce hydroponic production, but for a commercial production is indicated supplementation with nutrients like calcium, magnesium, and potassium in the system.

Acknowledgments The authors are grateful for all the support.

Funding information This study was supported by the Conselho Nacional de Desenvolvimento Científico e Tecnológico- $\mathrm{CNPq}$ (Project no. 444367/2014-4).

\section{References}

Adhikari S, Chaurasia VS, Naqvi AA, Pillai BR (2007) Survival and growth of Macrobrachium rosenbergii (De Man) juveniles in relation to calcium hardness and bicarbonate alkalinity. Turk J Fish Aquat Sci 7:23-26

Ayres M, Ayres JRM, Ayres DL, Santos AAS (2007) Bioestat: aplicações estatísticas nas áreas das ciências bio-médicas. Belém, Sociedade Civil Mamirauá

Carneiro PCF, Morais CAR, Nunes MUC, Maria AN, Fujimoto RY (2015) Produção integrada de peixes e vegetais em aquaponia. Aracaju: Embrapa Tabuleiros Costeiros, 2015a. 23p. (Embrapa Tabuleiros Costeiros. Comunicado Técnico, 189)

Castellani D, Camargo AFM, Abimorad EG (2009) Aquaponics: use of the effluent from the secondary nursery of Macrobrachium amazonicum for the production of hydroponic lettuce (Lactuca sativa) and watercress (Rorippa nasturtium aquaticum). Bioikos 23:67-75 (in Portuguese with English abstract)

Cerozi BS, Fitzsimmons K (2016) The effect of $\mathrm{pH}$ on phosphorus availability and speciation in an aquaponics nutrient solution. Bioresour Technol 219:778-781. https://doi.org/10.1016/j.biortech.2016.08.079

Chen RZ, Wong M-H (2016) Integrated wetlands for food production. Environ Res 148:429-442

Damasceno KSFSC, Andrade SAC, Stamford TLM (2009) Utilization of shrimp waste. Boletim do CEPPA 27:213-224 (in Portuguese with English abstract)

Dediu L, Cristea V, Xiaoshuan Z (2012) Waste production and valorization in an integrated aquaponic system with bester and lettuce. Afr J Biotechnol 11(9):2349-2358. https://doi.org/10.5897/AJB11.2829

Diver S (2006) Aquaponics - integration of hydroponics with aquaculture. National Sustainable Agriculture Information Service, $28 \mathrm{p}$

Dutra FM, Moretto Y, Portz L, Ballester ELC (2016) Pen culture of Macrobrachium amazonicum: use of artificial diet and impact on benthic community. Aquac Res 47:266-275

El-Sherif MS, Mervat AM (2009) Effect of rearing systems (mono- and polyculture) on the performance of freshwater prawn (M. rosembergii) juveniles. J Fish Aquat Sci 4:117-128

Emerenciano MGC, G1 M, Pinho SM, Molinari D, Blum MN (2015) Aquaponia: uma alternativa de diversificação na aquicultura. Panorama da Aquicultura, Rio de Janeiro, v 25:24-35 
FAO (2016) The state of world fisheries and aquaculture 2016. Contributing to food security and nutrition for all. Rome. $200 \mathrm{pp}$.

Geisenhoff LO, Jordan RA, Santos RC, de OFC, Gomes EP (2016) Effect of different substrates in aquaponic lettuce production associated with intensive Tilapia farming with water recirculation systems. Eng Agric 36(2):291-299. https://doi.org/10.1590/1809-4430-Eng. Agric.v36n2p291-299/2016

Genuncio GC, Gomes M, Ferrari AC, Majerowicz N, Zonta E (2012) Hydroponic lettuce production in different concentrations and flow rates of nutrient solution. Hortic Bras 30:526-530. https://doi.org/ 10.1590/S0102-05362012000300028

Guimarães IP, Oliveira FA, Torres SB, Pereira FECB, França FD, Oliveira MKT (2016) Use of fish-farming wastewater in lettuce cultivation. Rev Bras Eng Agríc Amb 20(8):728-733. https://doi.org/10.1590/ 1807-1929/agriambi.v20n8p728-733

Henares MNP, Preto B de L, Rosa FRT, Valenti WC, Camargo AFM (2015) Effects of artificial substrate and night-time aeration on the water quality in Macrobrachium amazonicum (Heller 1862) pond culture. Aquac Res 46:618-625. https://doi.org/10.1111/are.12208

Henry-Silva GG, Maia CSP, Moura RST, Bessa AP, Valenti WC (2015) Integrated multi-trophic culture of Nile tilapia (Oreochromis niloticus) and Amazon river prawn (Macrobrachium amazonicum) in brackish water. Arq Bras Med Vet Zootec 67:265-273. https://doi. org/10.1590/1678-6788

Hundley GMC, Navarro RD (2013) Aquaponia: a integração entre piscicultura e a hidroponia. Revista Brasileira de Agropecuária Sustentável, Viçosa, v 3:52-61. https://doi.org/10.21206/rbas.v3i2.218

Junge R, König B, Villarroel M, Komives T, Jijakli MH (2017) Strategic points in aquaponics. Water 9:182. https://doi.org/10.3390/ w9030182

Karplus I, Sagi A (2010) The biology and management of size variation. In: New b MB, Valenti WC, Ti- dwell JH, D'Abramo LR, Kutty MN (eds) Freshwater prawns: biology and farming. Wiley-Blackwell, Oxford, pp 316-345

Konnerup D, Trang NTD, Brix H (2011) Treatment of fishpond water by recirculating horizontal and vertical flow constructed wetlands in the tropics. Aquaculture 313:57-64. https://doi.org/10.1016/j. aquaculture.2010.12.026

Lennard WA, Leonard BV (2006) A comparison of three different hydroponic sub-systems (gravel bed, floating and nutrient film technique) in an aquaponic test system. Aquac Int 14:539-550. https://doi.org/ 10.1007/s10499-006-9053-2

Lin YF, Jing SR, Lee DY, Chang YF, Chen YM, Shih KC (2005) Performance of a constructed wetlands treating intensive shrimp aquaculture wastewater under high hydraulic loading rate. Environ Pollut Barking 134:411-421. https://doi.org/10.1016/j.envpol.2004. 09.015

Love DC, Fry JP, Genello L, Hill ES, Frederick JA, Li X, Semmens K (2014) An international survey of aquaponics practitioners. PLoS One 9:1-10. https://doi.org/10.1371/journal.pone.0102662

Maciel CR, Valenti WC (2009) Biology, fisheries, and aquaculture of the Amazon River prawn Macrobrachium amazonicum: a review. Nauplius 17:61-79

Mariscal-Lagarda MM, Páez-Osuna F, Esquer-Méndez JL, GuerreroMonroy I, Vivar AR, Félix-Gastelum R (2012) Integrated culture of white shrimp (Litopenaeus vannamei) and tomato (Lycopersicon esculentum Mill) with low salinity groundwater: management and production. Aquaculture 366:76-84. https://doi.org/10.1016/j. aquaculture.2012.09.003

Marques HLA, Barros HP, Mallasen M, Boock MV, Moraes-Valenti PMC (2012) Influence of stocking densities in the nursery phase on the growth of Macrobrachium amazonicum reared in net pens. Aquaculture 358-359:240-245. https://doi.org/10.1016/j. aquaculture.2012.06.011

Moraes-Valenti P, Morais PA, Preto BL, Valenti WC (2010) Effect of density on population development in the Amazon River Prawn
Macrobrachium amazonicum. Aquat Biol 9:291-301. https://doi. org/10.3354/ab00261

Moraes-Valenti PMC, Valenti WC (2007) Effect of intensification on grow out of the Amazon River Prawn, Macrobrachium amazonicum. J World Aquacult Soc 38:516-526. https://doi.org/ 10.1111/j.1749-7345.2007.00125.x

Moraes-Valenti P, Valenti WC (2010) Culture of the Amazon River prawn Macrobrachium amazonicum. In: New MB, Valenti WC, Tidwell JH, D'Abramo LR, Kutty MN (eds) Freshwater prawns: biology and farming. Wiley-Blackwell, Oxford, pp 485-501

Moraes-Riodades PMC, Kimpara JM, Valenti WC (2006) Effect of the Amazon river prawn Macrobrachium amazonicum culture intensification on ponds hydrobiology. Acta Limnol Bras 4(18):311-319

Negrini C, Castro CS, Bittencourt-Guimarães AT, Frozza A, OrtizKracizy R, Cupertino-Ballester EL (2017) Stocking density for freshwater prawn Macrobrachium rosenbergii (Decapoda, Palaemonidae) in biofloc system. Lat Am J Aquat Res 455:891-899

Nogueira M, Pinto FR, Nunes AP, Guariz CSL, Amaral LA (2014) Effluents quality during the grow-out phase of the Amazon shrimp Macrobrachium amazonicum. Cienc Anim Bras 15(2):159-167. https://doi.org/10.1590/1809-6891v15i219521

Pinheiro I, Arantes R, Espírito-Santo CM, Vieira FN, Lapa KR, Gonzaga LV, Fett R, Barcelos-Oliveira JL, Seiffert WQ (2017) Production of the halophyte Sarcocornia ambigua and pacific white shrimp in an aquaponic system with biofloc technology. Ecol Eng 100:261-267. https://doi.org/10.1016/j.ecoleng.2016.12.024

Paul P, Rahman A, Hossain MM, Islam S, Mondal S, Haq M (2016) Effect of stocking density on the growth and production of freshwater prawn (Macrobrachium rosenbergii). Int J Fish Aquac Sci 6:7786. https://doi.org/10.1590/S0101-81751993000300009

Pinho SM, Molinari D, Mello GL, Fitzsimmons KM, Emerenciano MGC (2017) Effluent from a biofloc technology (BFT) tilapia culture on the aquaponics production of different lettuce varieties. Ecol Eng 103:146-153. https://doi.org/10.1016/j.ecoleng.2017.03.009

Preto BL, Pizzato GM, Vallenti WC (2008) Use of feeding trays on growout phase of Amazon River prawn, Macrobrachium amazonicum (Heller, 1862). B Inst Pesca 34:125-130 (in Portuguese with English abstract)

Preto BL, Kimpara JM, Moraes-Valenti P, Valenti WC (2010) Population structure of pond-raised Macrobrachium amazonicum with different stocking and harvesting strategies. Aquaculture 307:206-211. https://doi.org/10.1016/j.aquaculture.2010.07.023

Preto BL, Kimpara JM, Moraes-Valenti P, Rosa FRT, Valenti WC (2011) Production strategies for short term grow-out of the Amazon River prawn Macrobrachium amazonicum (Heller 1862) in ponds. PanAm J Aquat Sci 6(1):1-8

Rakocy JE, Masser MP, Losordo TM (2006) Aquaponics-integrating fish and plant. Recirculating aquaculture tank production systems, SRAC publication no. 454 (Obtained from http://www2.ca.uky.edu/ wkrec/454fs.PDF on January 2017)

Rakocy JE (2007) Ten guideline for aquaponic systems. Aquaponics Journal 46:14-17

Rodrigues IN, Lopes MTG, Lopes R, Gama AS, Milagres CP (2008) Performance of lettuce cultivars in the region of Manaus. Hortic Bras 26:524-527. https://doi.org/10.1590/S010205362008000400020

Roosta HR (2014) Effects of foliar spray of K on mint, radish, parsley and coriander plants in aquaponic system. J Plant Nutr 37:2236-2254. https://doi.org/10.1080/01904167.2014.920385

Sace CF, Fitzsimmons KM (2013) Recirculating aquaponic systems using Nile tilapia (Oreochromis niloticus) and freshwater prawn (Macrobrachium rosenbergii) polyculture and the productivity of selected leafy vegetables. Merit Res J Bus and Manag 1:11-29. https://doi.org/10.15413/ajar.2013.0138

Sampaio CMS, Silva RR, Santos JA, Sales SP (2007) Reproductive cycle of Macrobrachium amazonicum females (Crustacea, 
Palaemonidae). Braz J Biol 67(3):551-559. https://doi.org/10.1590/ S1519-69842007000300022

Seawright DE, Stickney RR, Walker RB (1998) Nutrient dynamics in integrated aquaculture-hydroponics systems. Aquaculture 160: 215-237. https://doi.org/10.1016/S0044-8486(97)00168-3

Shi Y, Zhang G, Liu J, Zhu Y, Xu J (2011) Performance of a constructed wetland in treating brackish wastewater from commercial recirculating and super-intensive shrimp grow out systems. Bioresour Technol 102:9416-9424. https://doi.org/10.1016/j. biortech.2011.07.058

Sikawa DC, Yakupitiyage A (2010) The hydroponic production of lettuce (Lactuca sativa L.) by using hybrid catfish (Clarias macrocephalus $\mathrm{x}$ C. gariepinus) pond water: potentials and constraints. Agric Water Manag 97(9):1317-1325. https://doi.org/10.1016/j.agwat.2010.03.013

Somerville C, Cohen M, Pantanella E, Stankus A, Lovatelli A, (2014). Small-scale aquaponic food production: integrated fish and plant farming. In: FAO, U. (Ed.), FAO Fisheries and Aquaculture Technical Paper, Rome, pp. 1-262

Trang NTD, Brix H (2014) Use of planted biofilters in integrated recirculating aquaculture-hydroponics systems in the Mekong Delta, Vietnam. Aquac Res 45:460-469. https://doi.org/10.1111/j. 1365-2109.2012.03247.x

Tidwell JH, Bratvold D (2005) Utility of add substrates in shrimp culture. In: Periphyton - ecology, exploitation, and management (ed. by Azim ME, Verdegem MCJ, Van Dam AA, Beveridge MCM), pp. 247-268. CABI Publishing, UK
Timmons MB, Ebeling JM, Weathon FW, Summerfelt ST, Vinci BJ (2002). Recirculating aquaculture system, 2nd edition. Cayuga Aqua Ventures, Ithaca, New York, USA

UN-United Nations (2015) Transforming our World: the 2030 Agenda for Sustainable Development [online]. Resolution adopted by the General Assembly on 25 September 2015. A/RES/70/1. https:// sustainabledevelopment.un.org/post2015/transformingourworld/ publication

Wetzel JE (2001) A production methods for freshwater prawn in Illinois Ponds. Rural Enterprise and Alternative Development Initiative Report. Report No.10, 13 pp

Zachritz WH II, Hanson AT, Sauceda JA, Fitzsimmons KM (2008) Evaluation of submerged surface flow (SSF) constructed wetlands for recirculating tilapia production systems. Aquac Eng 39:16-23. https://doi.org/10.1016/j.aquaeng.2008.05.001

Zhang SY, Li G, Wu HB, Liu XG, Yao YH, Tao L, Liu H (2011) An integrated recirculating aquaculture system (RAS) for land-based fish farming: the effects on water quality and fish production. Aquac Eng 45:93-102. https://doi.org/10.1016/j.aquaeng.2011.08.001

Zou Y, Hu Z, Zhang J, Xie H, Guimbaud C, Fang Y (2016) Effects of pH on nitrogen transformations in media-based aquaponic. Bioresour Technol 210(2016):81-87. https://doi.org/10.1016/j.biortech.2015. 12.079

Publisher's note Springer Nature remains neutral with regard to jurisdictional claims in published maps and institutional affiliations. 